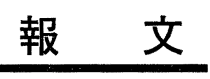

\title{
ジオレイルジメチルアンモニウム=クロリド/シクロヘキサン 溶液における水の可溶化状態と逆ミセル形成
}

\author{
今野紀二郎 ${ }^{* * *} \cdot$ 五野 正史 $*$ 河合 武司 ${ }^{*, * *}$ \\ * 東京理科大学工学部工業化学科 \\ ** 界面科学研究所 \\ ( 162 東京都新宿区神楽坂 1-3)
}

\begin{abstract}
Solubilized States of Water and Formation of Reversed Micelles of Dioleyldimethylammonium Chloride in Cyclohexane

\author{
Kijiro KON-NO**, Masashi ITsunO*, and Takeshi KAWAI**, \\ * Faculty of Engineering, Science University of Tokyo \\ ** Institute of Interface Science, Science University of Tokyo \\ (1-3, Kagurazaka, Shinjuku-ku, Tokyo, ₹162)
}

\begin{abstract}
Study was made to determine how the amounts of solubilized water depends on the concentration of dioleyldimethylammonium chloride in cyclohexane by Karl-Fisher titration at $25^{\circ} \mathrm{C}$. Using ${ }^{1} \mathrm{H}-\mathrm{NMR}$ and near infrared spectroscopy, the states of water in solubilization regions were examined as a function of $R w\left(=\left[\mathrm{H}_{2} \mathrm{O}\right] /[\right.$ surfactant $\left.]\right)$ at various surfactant concentrations. Three types of water were found present in different amounts within reversed micelles, that in the region below $R w=3.3$ was bound directly to polar groups of the surfactant ; that in $R w=3.3$ to 12.3 was held by hydrated polar groups through hydrogen bonding and that above $R w=12.3$ was bulk-like. These types are discussed in relation to the formation of reversed and swollen micelles or W/O microemulsions. The surfactant concentration and minimum $R w$ required for swollen micelle and $\mathrm{W} / \mathrm{O}$ microemulsion formation were determined.
\end{abstract}

\section{1 緒 言}

カチオン逆ミセルによる水の可溶化に関する研究は, アルキルアンモニウム脂肪酸塩/シクロヘキサン系 ${ }^{1)}$, あるいはジアルキルジメチルアンモニウムシハライド/ ベンゼン ${ }^{2)}$ およ゙塩化炭化水素系 ${ }^{3)}$ で行われてきたが, その報告はアニオンおよび非イオン逆ミセル系に比べ, かなり少ない。これは, カチオン界面活性剤のパラフィ ン族およびシクロパラフィン族炭化水素への溶解度が小 さいため, 用いられる溶媒の種類が限られるためと考え られる。最近, 著者 ${ }^{4}$ らは $\mathrm{NMR}$, 蛍光および近赤外分 光法を用い, ブチルドデシルジメチルアンモニウム=ブ ロミド/クロロベンゼン系における水の可溶化状態を詳 細に研究し, そのミセル内部に可溶化状態の異なる 3 種 類の水がある割合で存在することを明らかにした。そし

連絡者 : 今野紀二郎
て, それらの水の可溶化状態を逆ミセル, 膨潤ミセルお よび W/O マイクロエマルション形成と関連づけた。し かし，この第四級アンモニウム型カチオン性逆ミセル内 部の可溶化水を反応場として, $\mathrm{Au}, \mathrm{Pt}$ 等の金属あるい は $\mathrm{CdS}, \mathrm{AgCl}$ 等の半導体超微粒子を合成し, それらの 分光学的測定をin situ で行った場合, それら粒子の特 性吸収が溶媒のクロロベンゼンのそれと重なり測定が困 難となる。したがって，パラフィン系あるいはシクロパ ラフィン系炭化水素への溶解度が大きく，しかも大きな 水の可溶化能を有するカチオン界面活性剂の出現が望ま れていたが，幸いにもジメチルジオレイルアンモニウム =クロリドはシクロヘキサンへの溶解度が大きく, しか も大きな水の可溶化能を有することがわかった。

そこで, カチオン性逆ミセル系における金属超微粒子 等の合成とその分光学的性質を調べるための基礎研究と して, 本研究では, まず微䉼子合成の反応場である可溶 化水に注目し, シクロヘキサン中で形成するジメチルジ 
オレイルアンモニウム=クロリド逆ミセルによる可溶化 水の溶解状態を既報 ${ }^{4)}$ の場合と同様に NMR および近 赤外分光法で調べることにした。そして, 得られた溶解 状態は逆ミセル形成と関連づけ, ミセル形成パラメー

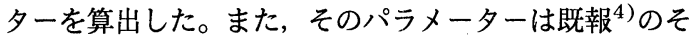
れと比較した。

\section{2 実 験}

\section{$2 \cdot 1$ 試 料}

ジメチルジオレイルアンモニウム=クロリド（以下， DODAC と略記する) は，ライオン(株)社から提供さ れたもので以下の操作にしたがって精製して用いた。す

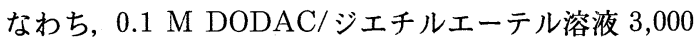
$\mathrm{mL} に 60 \mathrm{~g}$ の水を加え, マグネチックスターラーで充 分かき混せたのち, 室温で静置し, 透明溶液を分離し た。この操作をさらに 2 回繰り返したのち, 溶媒を留去 し, メタノール溶液中で活性炭処理を行った。得られた DODAC を減圧下 $60^{\circ} \mathrm{C}$ で乾燥し，それを乾燥シクロへ キサンへ溶解し, 不溶解分をメンブランフィルター $(0.24 \mu \mathrm{m})$ で除いたのち, 再び減圧下 $60^{\circ} \mathrm{C}$ で乾燥し た。シクロへキサンは，市販特級品を特に精製せずに用 いた。水はイオン交換水を蒸留して用いた。

\section{$2 \cdot 2$ 水の可溶化限界量測定}

水の可溶化限界量は, 既報)の方法にしたがって行っ た。すなわち，一定濃度の DODAC/シクロへキサン溶 液へ水あるいは水/DODAC コンプレックスの析出物の 少量が界面活性剂溶液から分離するまで加えたのち, 25 ${ }^{\circ} \mathrm{C}$ の恒温水槽中に 1 週間静置した。その後, 得られた 透明な界面活性剂溶液中の水分量をカールフィシャー水 分測定装置で測定した。そこで，水を添加しない界面活 性剂溶液中の水分量は, 界面活性剂に対するモル比で 0.02 以下であった。

\section{$2 \cdot 3$ 可溶化水の化学シフトおよび近赤外スペクトル} 測定

可溶化水の化学シフト $(\delta)$ は, 外部基準として TMS を用い，日立製作所(株)社製 R-24 B 型 NMR で測定 した。一方, 近赤外スペクトルは, 日立 330 分光光度計 を用い, $0.1 \mathrm{~mol} \cdot \mathrm{kg}^{-1} \mathrm{DODAC} /$ シクロヘキサン溶液へ $\mathrm{D}_{2} \mathrm{O}$ 水溶液 $\left(90 \% \mathrm{D}_{2} \mathrm{O}+10 \% \mathrm{H}_{2} \mathrm{O}\right)$ を可溶化し，その 溶液中の水の $\mathrm{OH}$ 伸縮振動の倍音 $(2 \nu \mathrm{OH})$ 領域で測定 した。ここで, $\mathrm{D}_{2} \mathrm{O}$ は水分子内の $\mathrm{OH}$ 伸縮振動のカッ プリングを避けるために用いた。なお，測定温度はいず

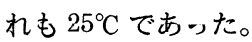

\section{$2 \cdot 4$ 逆ミセル量の測定}

平均ミセル量は, 可溶化溶液の光散乱および屈折率を $25^{\circ} \mathrm{C}$ で大塚電子(株)社製 DLS-700 型光散乱光度計およ び DRM-1020 ダブルビーム示差屈折計で測定し, Debye プロットから算出した。なお，DODAC の臨界ミ
セル濃度 $(\mathrm{cmc})$ は測定していないが, この種の界面活 性剂のミセルは逐次的に形成する5)ことから $\mathrm{cmc}$ が存 在するかは疑問であるため, シクロへキサン中の酪酸ド デシルアンモニウムの $\mathrm{cmc}$ が $2 \times 10^{-3} \mathrm{~mol} \cdot \mathrm{dm}^{-3}$ 6) で あることを参考にして $10^{-3} \mathrm{~mol} \cdot \mathrm{kg}^{-1}$ とした。

\section{3 結果と考察}

\section{$3 \cdot 1$ 水の可溶化限界量}

DODAC 溶液における水の可溶化状態を調べる前 に, 水の可溶化限界量の界面活性剂濃度依存性を測定し た。限界量は, Fig.-1 に見られるように, $10 \mathrm{mmol}$. $\mathrm{kg}^{-1}$ まで徐々に直線的に増加し, その後は急激に, し かも再び直線的に増大した。ここで, $10 \mathrm{mmol} \cdot \mathrm{kg}^{-1}$ ま での增大は, カチオン界面活性剂のミセル会合数が界面 活性剤濃度とともに徐々に増大する ${ }^{5)}$ ことから考え，小 さな会合体によるものであり, その後の急激な増大は比 較的会合数の大きなミセルによるものと考えられる。し たがって, 可溶化量が急激に増大する界面活性剂濃度 は, 実効臨界ミセル濃度と言えるかも知れないが, 後述 するように，この濃度以上で膨潤ミセルおよび W/O マ イクロエマルション形成することから，ブチルドデシル ジメチルアンモニウムニブロミド (以後, BDDAB と略 記する ${ }^{4)}$ および Aerosol $\mathrm{OT}^{7)}$ 逆ミセル系の場合と同

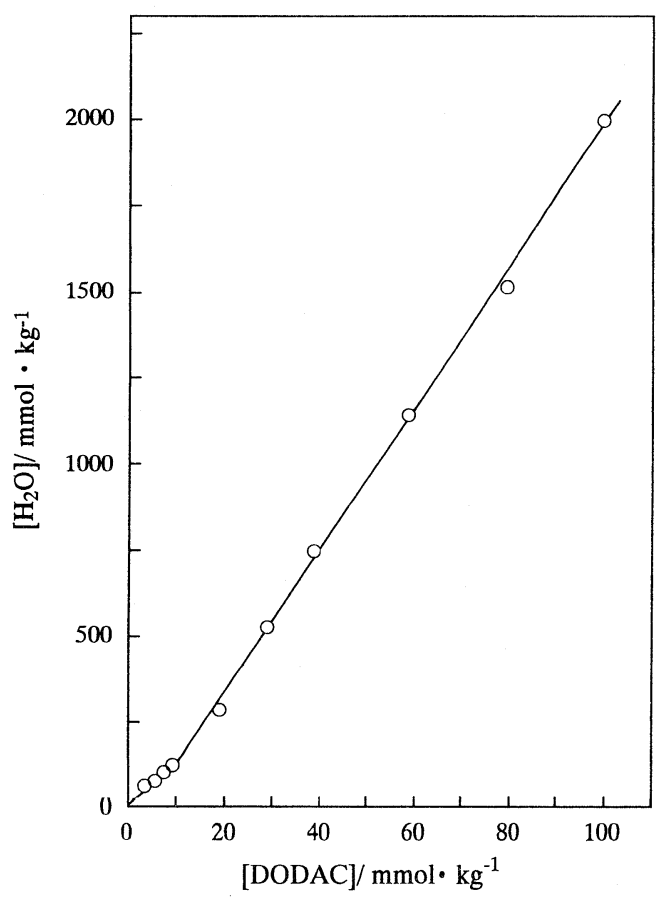

Fig. -1 Change of the limiting amounts of solubilized water with [DODAC] in cyclohexane. 
様に, 膨潤および W/O マイクロエマルション形成濃度 (以後, $C_{\mathrm{swc}}$ と略記する) とした。そこで, その濃度以 下および以上の直線の勾配から, それぞれ会合体および ミセルの可溶化能 (以後, それぞれ $S P_{\mathrm{a}}$ および $S P_{\mathrm{m}}$ と略記する）を算出した。

\section{$3 \cdot 2$ 水の可溶化状態}

著者ら ${ }^{4), 7) ~ 10) ~}$ は, すでにイオン性あるいは非イオン 性逆ミセル溶液における水の可溶化状態を ${ }^{1} \mathrm{H}-\mathrm{NMR}$, ESR, 蛍光および近赤外法で詳細に研究し, それらのミ セル内部に可溶化状態の異なる水が存在することを示し た。これらの水の存在は, NMR による可溶化水の化学 シフトの $R w\left(=\left[\mathrm{H}_{2} \mathrm{O}\right] /[\right.$ 界面活性剂] $)$ 変化が $\mathrm{ESR}$ お よび蛍光プローブ法で測定した回転相関時間, 超微細構 造定数あるいは内部緩和時間から見積もられる可溶化水 の極性あるいは微視的粘度等の変化之関連づけられ, さ らにそれらの結果が近赤外スペクトルの $R w$ 変化と関 連づけられることから明らかにした。そこで，ここでは NMR と近赤外の 2 方法で DODAC 逆ミセル内部の水 の可溶化状態を調べることにした。Figs.-2 および -3 には, Fig.-1に基づいて測定した種々の DODAC 濃度 における可溶化水の化学シフト $(\delta)$ および近赤外スペ クトルの $R w$ 変化を示した。 $\delta$ 值は, いずれの DODAC 濃度においても $R w$ の増大とともに低磁場シフト し, $R w$ がほぼ 4 および 12 付近で屈折したが, その值は

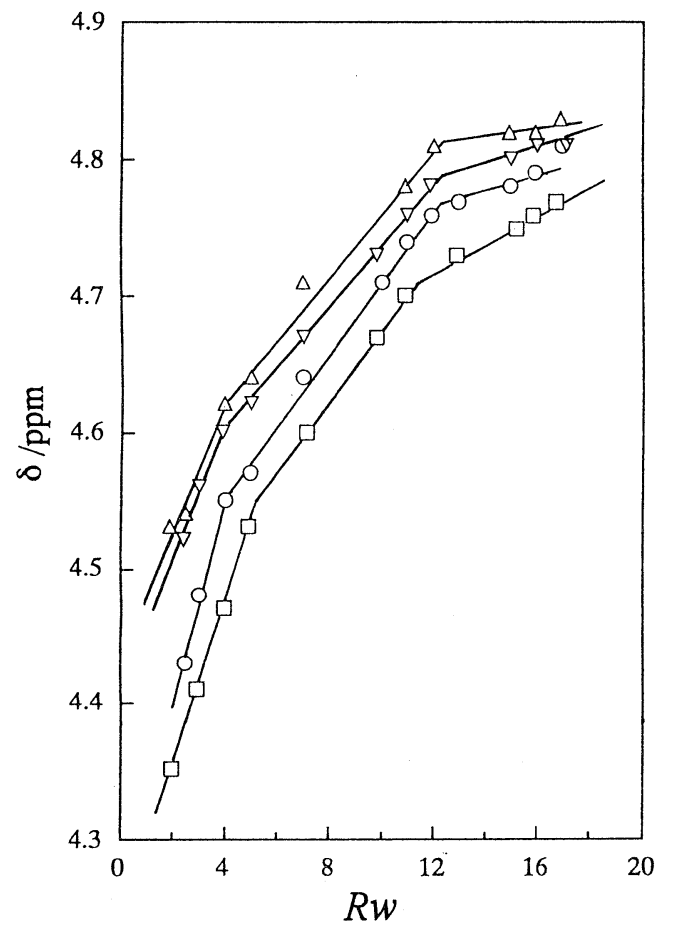

Fig.-2 Change of $\delta$ with $R w . \square, \bigcirc, \nabla, \triangle$ at 40 , $60,80,100 \mathrm{mmol} \mathrm{kg}^{-1}$, respectively.
可溶化限界点に近づいてもバルク水のそれには達しな かった。一方, 近赤外スペクトル変化は, Fig. -3にみ られるように, 水素結合に起因しない, いわゆるフリー な水の $\mathrm{OH}$ 伸縮振動に州属する $1,420 \mathrm{~nm}$ の吸収は $R w$ とともに限界点まで増大し, 水分子同士間の水素結合に 起因する $1,650 \mathrm{~nm}$ の吸収は $R w=3.7$ 以上で現れ，そ の強度は $R w=10.9$ 以上で急増した。この後者の吸収の 出現および急増する $R w$ 值は, Fig. -2 中の $\delta$ が屈折す る $R w$ 值とほぼ一致した。同様な結果は, 既報のイオ

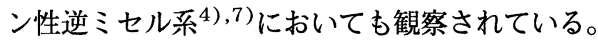

ここで, $1,420 \mathrm{~nm}$ の吸収が $R w$ とともに増大したの は, BDDAB 系にみられるように $R w$ とともにミセル が膨潤し ${ }^{4)}$, 界面活性剂の極性基部への水の結合サイト が増大するためと考えられる。しかし， $\delta$ 值の 2 つの屈 折点の出現はミセル内部に可溶化状態の異なる 3 種類の 水が存在することを示しており, その状態は近赤外スペ クトル変化から説明することができる。すなわち, 1,420 $\mathrm{nm}$ の吸収の変化からは, 水素結合を有しない 水, すなわち界面活性剤の極性基部である $=\mathrm{N}^{+}\left(\mathrm{CH}_{3}\right)_{2}$ $\mathrm{Cl}^{-}$一直接結合する水が可溶化初期から限界点までの領 域で存在し,一方 $1,650 \mathrm{~nm}$ の吸収が出現し, その強度

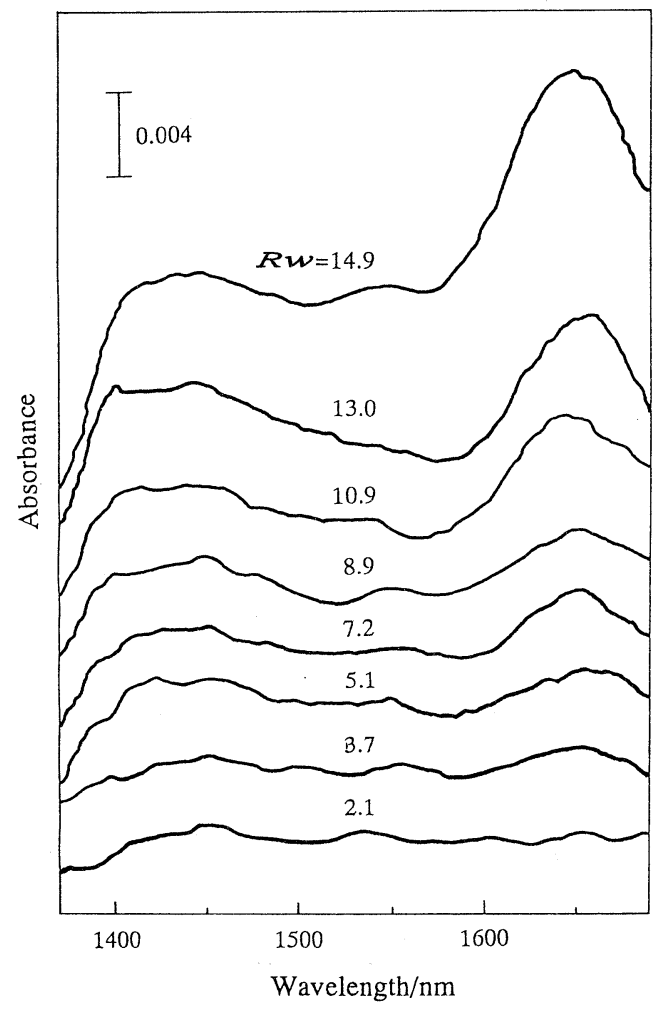

Fig. -3 Change of near-infrared spectra in the $\mathrm{OH}$ overtone stretching region with $R w$ at $0.10 \mathrm{~mol} \cdot \mathrm{kg}^{-1}$ DODAC. 
が徐々に増大する $R w=4$ から 11 付近までの領域では, その水和極性基部へ水素結合によって結合する水相が形 成し, さらにその吸収が急増する $R w=11$ 以上の領域で は水同士の水素結合による, いわゆるバルク類似水相が 形成することがわかる。この後者の 2 種類の水は, イオ

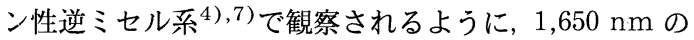
吸収が急増する領域では蛍光プローブの内部緩和時間の 值がバルク水中で得られるそれとほとんど一致すること から区別することができる。

\section{$3 \cdot 3$ 水の可溶化状態と逆ミセル形成との関連性}

上述のように, 逆ミセル内部には可溶化状態の異なる 3 種類の水が存在することがわかったが, これらの領域 は, Fig. -4 に示すように $\delta$ 值の屈折点に相当する $R w$ 值 (Fig. - 2) を Fig. -1 中の水の可溶化領域内にプロッ トすることによって, 領域 I, IIおよび吕として見積も ることができる。これらの水の可溶化状態の違いは, ま た逆ミセル形成へ反映するものと考えられることから，

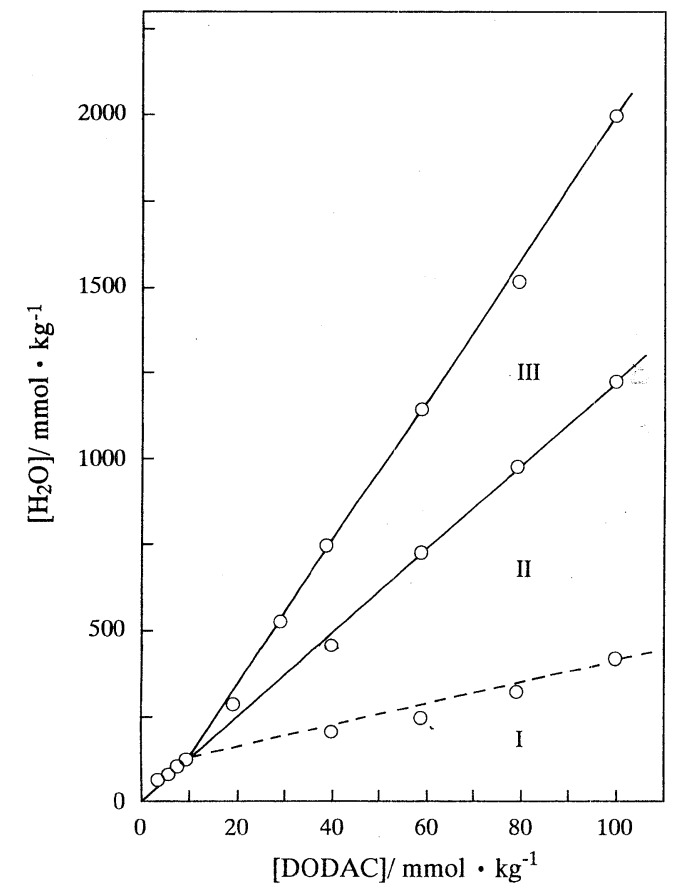

Fig. -4 Phase diagram of solubilization of water in DODAC/cyclohexane system.
光散乱法でそれぞれの領域におけるミセルの見掛けの平 均会合数 $(\bar{n})$ の $R w$ 変化を測定した。その結果, Fig. -5 にみられるように, $\bar{n}$ 值は $R w=4$ 付近から增大し, $R w=12$ 以上からは急激に増大した。これら $\bar{n}$ の増大す る $R w$ 值は, $\delta$ が屈折する $R w$ 值と一致し, 水の可溶 化状態の違いが逆ミセルの大きさへ反映することがわ かった。そこで, イオン性 $\left.{ }^{4)}, 7\right)$ およ゙非イオン性逆ミ セル系8) 10) と同様に領域 I, II およびIIIで形成するミ セルを，それぞれ逆ミセル，膨潤ミセルおよび W/O マ イクロエマルションと命名した。したがって, Fig. -4 の水の可溶化状態図は, また逆ミセル状態図と呼ぶこと もできる。

\section{$3 \cdot 4$ 逆ミセル形成パラメーター}

Fig. -4 からわかるように, 可溶化限界量が急増する 界面活性剂濃度以上で䐍潤ミセルおよび W/O マイクロ エマルションが形成することから，この濃度を前述した ように $C_{\mathrm{swc}}$ とした。一方, Fig.-4 中に示した点線お よび実線の直線の勾配は, 膨潤ミセルおよび W/O マイ クロエマルション形成に要する水の最少 $R w$ 值（それ

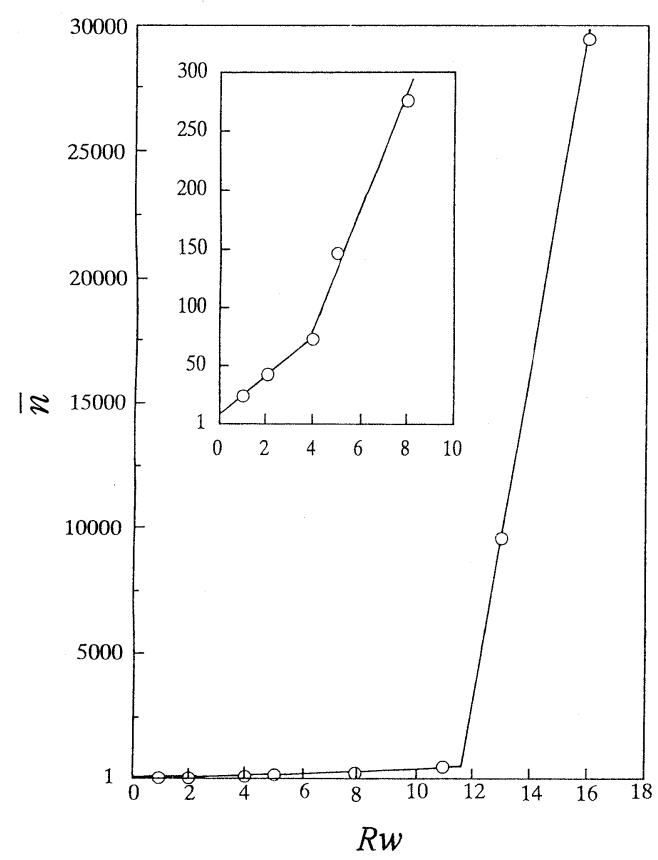

Fig. -5 Plots of $\bar{n} v s$. Rw.

Table-1 Parameters of micellar formation and solubilization powers of water.

\begin{tabular}{lccccccc}
\hline Surfactant & Solvent & Temp. $/{ }^{\circ} \mathrm{C}$ & $C_{\mathrm{swc}}{ }^{* 1}$ & $R_{\mathrm{SMs}}$ & $R_{\mathrm{w} / \mathrm{o}}$ & $S P_{\mathrm{a}}$ & $S P_{\mathrm{m}}$ \\
\hline DODACPP & Cyclohexane & 25 & 0.01 & 3.3 & 12.3 & 12.0 & 20.9 \\
BDDAB & Chlorobenzene & 30 & 0.01 & 3.7 & 11.0 & 2.6 & 30.3 \\
\hline
\end{tabular}

*1 Unit : $\mathrm{mol} \cdot \mathrm{kg}^{-1}$ 
ぞれ $R_{\mathrm{SMs}}$ および $R_{\mathrm{w} / \mathrm{o}}$ と略記する）を与える。そこ で，それらの直線について $C_{\mathrm{swc}}$ における水濃度および $C_{\mathrm{Swc}}$ を補正し， $R_{\mathrm{SMs}}$ および $R_{\mathrm{w} / \mathrm{o}}$ 值を算出した。得 られた值は, 界面活性剂の分子構造, 溶媒および温度が 異なるため直接比較することはできないが, 同族体の BDDAB のミセル系で得られた值 ${ }^{4)}$ と $S P$ 值とを一緒 に Table-1 に示した。Table-1 からわかるように, DODAC 系の逆ミセル形成パラメーターである $C_{\mathrm{swc}}$, $R_{\mathrm{SMs}}$ および $R_{\mathrm{w} / \mathrm{o}}$ は $\mathrm{BDDAB}$ 系のそれとほぼ同程度 の値を示したが, 水の可溶化能すなわち $S P_{\mathrm{a}}$ および $S P_{\mathrm{m}}$ 值が異なることがわかる。

ここで, 両者の界面活性剂で逆ミセル形成パラメー ターの $R_{\mathrm{SMs}}$ および $R_{\mathrm{w} / \mathrm{o}}$ がほぼ同程度の值を示した のは, これらの值が界面活性剂の極性基部の水和数に反 映することによるものと考えられる。すなわち，もし両 界面活性剤の極性基部の溶媒和が溶媒の種類にかかわら ず同程度で，しかも，その水和数がイオン界面活性剂で あるため $25^{\circ} \mathrm{C}$ と $30^{\circ} \mathrm{C}$ との間でほとんど变わらないとす ると, $\mathrm{Cl}^{-}$と $\mathrm{Br}^{-}$の水和数が同じであるため ${ }^{11)}$, 両者 の界面活性剂で同程度の $R_{\mathrm{SMs}}$ と $R_{\mathrm{w} / \mathrm{o}}$ 值が得られた ものと考えられる。一方, $\left(S P_{\mathrm{m}}-S P_{\mathrm{a}}\right)$ 值から見積もら れるW/O マイクロエマルション領域の大きさは, 両者 の界面活性剂間で著しく異なった。これは，一般に $S P_{\mathrm{m}}$
が極性基部の水和数のほかに, アルキル基の bulkiness や溶媒の種類等の因子に依存するためと考えられる ${ }^{12)}$ 。 〔平成 7 年 (1995 年) 4 月 17 日受理〕

\section{文献}

1) K. Kon-No, A. Kitahara, J. Colloid Interface Sci., 33, 124 (1970)

2）今野紀二郎, 大野 允, 北原文雄, 日化, 91,598 (1970)

3) R.E. Verrall, S. Milioto, R. Zana, J. Phys. Chem., 92, 3939 (1988)

4) T. Kawai, K. Hamada, K. Kon-No, Bull. Chem. Soc. Jpn., 66, 2804 (1993)

5) K. Kon-No, H. Asano, A. Kitahara, Progr. Colloid Polymer Sci., 68, 20 (1983)

6) A. Kitahara, J. Colloid Sci., 12, 342 (1957)

7) T. Kawai, K. Hamada, N. Shindou, K. Kon-No., Bull. Chem. Soc. Jpn., 65, 2715 (1992)

8) T. Kawai, N. Shindou, K. Kon-No., Colloid Polymer Sci., 273, 195 (1995)

9) T. Kawai, K. Hamada, N. Shindou, K. Kon-No., J. Surface Sci. Technol., 8, 45 (1992)

10) 今野紀二郎, 森田健司, 永沢裕之, 河井武司, 油化学, 43, 490 (1994)

11）化学便覧基礎編（改訂 3 版）Vol. II, p. 717, 丸善 (1984)

12）今野紀二郎, 上野雄二, 石井靖人, 北原文雄, 日化, 381 (1970) 